\title{
REPOSITIONING VOCATIONAL AGRICULTURAL EDUCATION PROGRAMMES IN UNIVERSITIES FOR THE REALIZATION OF FOOD SECURITY IN RIVERS STATE, NIGERIA
}

\author{
EKEZIE, ANTHONY IMO A., PhD \\ Associate Professor of Agricultural Education, \\ Department of Vocational and Technology Education, Rivers State University, \\ P. M. B. 5080, Port Harcourt, Nigeria \\ $+2347035477126$
}

https://doi.org/10.37602/IJSSMR.2020.3310

\begin{abstract}
The study hinges on repositioning vocational agricultural education programmes in universities for the realization of food security in Rivers State, Nigeria. The descriptive survey design was used for the study that has a population of 28 Agricultural education lecturers from Rivers State University, Port Harcourt and the Ignatius Ajuru University of Education, Rumuolumeni, Port Harcourt. Two research questions guided the study. A 20item self-structured questionnaire composed on a 5-point Likert scale and titled "Repositioning Vocational Agricultural Education for Food Security Questionnaire (RVAEFSQ)", was used for data collection. RVAEFSQ was face-validated by two experts in vocational agricultural education from Niger Delta University, Amassoma, Bayelsa State. The reliability of the instrument was established using Cronbach's Alpha method which yields a reliability coefficient of 0.89 . Mean and the standard deviation was used for data analysis. The result revealed that inadequate lecturers, unavailability of pilot farms, poor research funding and poor teaching facilities among others are major challenges of vocational agricultural education in Rivers State. Thus, it was recommended that Government should enhance the quality of vocational agricultural education in universities in Rivers State through the provision of pilot farms, adequate funds, training facilities among others so as to guarantee food security in Rivers State, Nigeria.
\end{abstract}

Keywords: Vocational agricultural education, food security, economic development, food insecurity.

\subsection{INTRODUCTION}

One of the three basic necessities of life aside shelter and clothing is food. Food is very necessary because it serves as the fuel supplying living things (including humans) with the energy needed by the body to perform daily tasks. According to Matemilola and Elegbede (2017), food is no doubt, the most essential of all human survival needs. As humans, we all need food to survive. Muhammad-Lawal, Salau and Olawusi (2015) report that Nigeria is grossly an agrarian state having over $70 \%$ of her economically active population employed in the agricultural sector. Although Nigeria is richly endowed with fertile lands that support 


\section{International Journal of Social Sciences and Management Review}

Volume: 03, Issue: 03 "May - June 2020"

ISSN 2582-0176

agricultural activities capable of enhancing food production to meet the nutritional needs of teeming Nigeria's population, the country is still wallowing in short supply of food. That is to say that the country is experiencing food insecurity as the price of agricultural products increases geometrically. Again, as the population of the country increases, so is the demand for food leading to short supply of food. According to Food Agricultural Organization (FAO) (2010), food insecurity refers to the significances of insufficient consumption of nutritious food, considering the physiological use of food by the body as being within the domain of nutrition and health. Though food insecurity is a global phenomenon, it is more prevalent in the developing nations including Nigeria (Matemilola \& Elegbede, 2017). Food insecurity has persisted in Nigeria and many other developing nations of the world due to inefficient Government policies with respect to agriculture, trade, economics and other adjourning sectors. The failure of governments in many third world countries in implementing good policies in agriculture, food supply, trade, and economics results to intense hunger and malnourishment in the world (Behnassi, Draggan, \&Yaya, 2011). Food insecurity is therefore strongly linked with other global issues, such as population growth, surge in energy demand, environmental degradation, erosion, drought, climate change, oil spillage among others (Behnassi, Pollmann \& Kissinger, 2013). According to Otaha (2013), food insecurity occurs when people are malnourished as a result of the physical unavailability of food, their lack of social or economic access to adequate food as well as their inability to purchase it when available to the hike in price. Thus, food-insecure people are those whose food intake falls below their lowest energy requirements as well as those who display physical symptoms activated by energy and nutrient deficits resulting from an insufficient or unbalanced diet or from the body's inability to effectively use food due to infection or disease. Hence, there is an urgent need for Nigeria to work assiduously towards achieving food security for its teeming population as no meaningful economic development is possible without a massive food supply.

Food security, therefore, addresses a situation where there is availability, accessibility and utilization of food by the teeming population of a country. Food security involves access and availability of foodstuff, the stability of supplies and the quality of the diet (Olayinka, 2017). Food security is a state where food is available at all times, to which all persons have means of access, and where there is a nutritionally adequate supply of it in terms of quantity, quality and variety, and is acceptable within a given culture (Clover, 2003). In essence, a country should be considered as food-secure when food is not only available in the quantity needed by the population consistent with decent living, but also when the consumption of the food should not pose any health hazard to the citizens (Davies, 2009). To achieving food security in Rivers State and Nigeria as a whole, there needs to be increased agricultural production activities by indigenous farmers. According to Igbinedion and Aihie (2015), food security remains an elementary and basic requisite for national development and as such, has been used by different people to convey different thoughts. In the views of Ojo and Adebayo (2012), food security refers not only to an adequate collective supply of food, but also means that all people at all times have both physical and economic access to basic food. A food secured situation is said to exist when the demand side is balanced with the supply side, anything contrary to that denotes food insecurity (Egbuna, 2001). Hence, availability, access, affordability and usability are all elements of food security complex issues that encompass a wide range of interrelated economic, social and political factors daring Africa's ability to address food insecurity issues within its territory. Therefore, attempting to remedy Nigeria's 


\section{International Journal of Social Sciences and Management Review}

Volume: 03, Issue: 03 "May - June 2020"

ISSN 2582-0176

agricultural production saga causing the short supply of food for the teeming populace, there is a crucial need for Government to reposition vocational agricultural education programmes of universities in Nigeria to ensure their effectiveness in instilling relevant agricultural skills in the students (learners) for massive food supply in Nigeria. This could be achieved by motivating them to pursue a career in vocational agricultural education.

Traditionally, vocational education entails any form of education designed to train learners in relevant knowledge, skills, competencies and attitudes for specific occupations (Nwankwo, 2000). Thus, vocational skills development which is gained via vocational education is very essential if students must become job creators rather than job seekers. Recipients of vocational education are assumed to have already chosen their life occupations and thus need all necessary training to acquire relevant skills and knowledge to enable them develop their expertise and progress in their chosen careers. Developing vocational skills in agriculture by the students is crucial for food security, poverty alleviation and eradication, economic advancement, social development and environmental sustainability (Amadi \& Nnodim, 2018). Quality vocational agricultural education, therefore, is key to achieving food security in Nigeria.

Vocational agricultural education as an aspect of vocational education refers to the study of the interrelationship between agriculture as a discipline and the teaching of skills, knowledge, values and attitudes leading to the production of goods, processing and marketing of agricultural and related products for economic development (Arokoyu \& Ndeobi, 2014). Similarly, Adah and Adejohn (2004) posit that vocational agricultural education tests its validity via results, emphasizing the analytical and prescriptive approaches of education. Vocational agricultural education is being taught at all levels of education in order to inculcate relevant skills and knowledge in the learners which are crucial to sustaining them upon graduation, thereby making them productive, self-reliant and employers of labour in any agro-based vocations of their choice (Amadi \& Nnodim, 2018). Likewise, Ekezie and Owo (2019) postulate that vocational agricultural education is an aspect of education aimed at equipping both students and teachers with adequate knowledge, relevant skills and abilities to set up and manage agricultural farms for massive food supply. In the same vein, Wikipedia (2016) describe vocational agricultural education as the teaching of agriculture, natural resources and land management through hands-on experience and guidance so as to prepare students for entry-level jobs or to further education, to prepare them for advanced agricultural careers including food production. Furthermore, Arokoyu \& Ndeobi (2014) stated that vocational agricultural education provides learners with relevant personal, academic and career experiences and competencies required for active participation in agricultural entrepreneurship. Again, Dipaharima (2004) sees vocational agricultural education as a tool for the promotion of agricultural knowledge and skills in the individuals for innovative skills development necessary for environmental management for the economic development of the nation. According to Usman and Sulaiman (2006), vocational agricultural education is concerned with the development of skills; knowledge and attitude in the field of agriculture to enable the recipients to take up a career in it. Vocational Agricultural education in the words of Ezeagu and Ezema, (2004) trains agricultural personnel in the aspects of growing of crops, rearing of animals, horticulture, farm management among others for increased food security. Vocational agricultural education covers animal production/science; crop science/production; horticulture; agricultural extension, agricultural engineering, veterinary medicine among 


\section{International Journal of Social Sciences and Management Review}

others in which agricultural students can avail themselves of the opportunity for the development of requisite skills suitable for the economic development of the nation (Obinne, 2002). Therefore, vocational agricultural education may help to boost massive food supply in the country and beyond if properly administered in our tertiary institutions as no meaningful progress can be made in terms of food security in Nigeria until the people are adequately trained to acquire modern agricultural production skills that can enhance their careers in agricultural food production. Agricultural education as a vocational programme involves a gradual integration of various agricultural skills in the learner for increased productivity (Ekezie \& Owo, 2019). Therefore, owing to the significance of vocational agricultural education in ensuring food security in Nigeria, it becomes imperative for the researcher to find out how vocational agricultural education can be repositioned to boost food supply in Rivers State, Nigeria.

Although vocational agricultural education is a programme run by universities in Rivers State and other parts of the country to help train local personnel and educators interested in pursuing a career in agriculture for massive food production, its impact in boosting food security is not adequately felt due to the constraints faced by universities offering vocational agricultural education programmes in Rivers State, Nigeria as it was observed that most students who enrolled in the programme are not willing to pursue a career in vocational agricultural education after their graduation (Ekezie \& Owo, 2019; Nwankwo, 2000) as a result of inadequate skills acquisition and unfavourable agricultural policies of Government which impede on the efficacy of the programme. Likewise, Amadi and Nnodim (2018) posit that poor curriculum, inadequate competent instructors, inadequate agricultural training facilities and materials, lack of pilot farms, ill-equipped libraries, inadequate funding, poor staff welfares, inadequate processing and storage facilities among others constitute some major issues affecting vocational agricultural education in Nigeria which hamper on its output. In order to offer solutions to the issues affecting vocational agricultural education to ensure massive food supply in Rivers State, Nigeria, this study was conducted to ascertain how vocational agricultural education programme in Universities can be repositioned for the realization of food security in Rivers State, Nigeria.

Based on the constraints to effective vocational agricultural education in Nigerian universities, this study was conducted to ascertain how vocational agricultural education programmes in universities can be repositioned for the realization of food security in Rivers State, Nigeria. Specifically, the study sought to:

- Determine the challenges of vocational agricultural education programmes in universities which work against the realization of food security in Rivers State, Nigeria.

- Determine possible ways of tackling the challenges of vocational agricultural education programmes in universities for the realization of food security in Rivers State, Nigeria.

- Thus, from the study objectives itemized above, the following two research questions were posed to guide the study: 


\section{International Journal of Social Sciences and Management Review}

- What are the challenges of vocational agricultural education programmes in universities which work against the realization of food security in Rivers State, Nigeria?

- What are the possible ways of tackling the challenges of vocational agricultural education programmes in universities for the realization of food security in Rivers State, Nigeria?

\subsection{MATERIALS AND METHODS}

\subsection{Design of the Study}

The study adopts a descriptive survey design. A descriptive survey design according to Nwankwo (2016) is that in which the researcher collects data from a large sample drawn from a given population and describes certain features of the sample as they are at the time of the study and which are of interest to the researcher, although without altering any independent variables of the study. Furthermore, Akaninwor (2014) posits that in a descriptive design, there is no manipulation of the independent variables of the study. The independent variables of the study are the problems facing vocational agricultural education programs in Rivers State universities which the study seeks to remedy. These challenges include poor training facilities and inadequate lecturers among others.

\subsection{Research Type/Area of the Study}

This is an empirical study carried out in Rivers State, Nigeria.

\subsection{Research Duration}

The duration of the study was 12 weeks. The research commenced in November 2019 and was concluded in January 2020. 3 weeks out of the 12 weeks was used for instrument administration and retrieval of same from the respondents.

\subsection{Inclusion and Exclusion Criteria}

Vocational Agricultural Education programmes in the two Rivers State Universities were considered for the study. Thus, all lecturers of Agricultural education in both universities were considered and included in the study since they deal directly with agricultural education and have experienced the challenges hampering food security in Nigeria which can be addressed via quality agricultural education. Meanwhile, students of Agricultural education in these two universities in Rivers State, Nigeria were excluded from the study owing to the fact that they may not have detailed knowledge of the challenges associated with the administration of agricultural education programmes in Universities in Rivers State, Nigeria. Again, other vocational education lecturers who do not specialize in agricultural education were excluded from the study as they may not have good knowledge of the challenges of agricultural education since it is not their area of research interests. 


\section{International Journal of Social Sciences and Management Review}

Volume: 03, Issue: 03 "May - June 2020"

ISSN 2582-0176

\subsection{Population of the Study}

The population of the study comprised 28 Agricultural education lecturers from Rivers State University, Port Harcourt and the Ignatius Ajuru University of Education, Port Harcourt.

\subsection{Sampling and Sampling Technique}

Purposive sampling technique was used to select all the 24 Agricultural education lecturers in the two universities in Rivers State for the study. The sample of the study was the same as the population since its of manageable size.

\subsection{Choice of Subjects}

All Agricultural education lecturers in Rivers State University, Port Harcourt and the Ignatius Ajuru University of Education, Port Harcourt were selected as the population of the study. The choice is based on the fact that they are specialists in agricultural education, hence they adjudged to have possessed a good knowledge of the problem facing the agricultural education programme in the universities and the way forward.

\subsection{Instrument for Data Collection}

The instrument for data collection was the researcher's self-constructed 20-item questionnaire titled "Repositioning Vocational Agricultural Education for Food Security Questionnaire (RVAEFSQ)". RVAEFSQ was constructed on a 5-point Likert Scale of Strongly Agree, Agree, Undecided, Disagree and Strongly Disagree corresponding to numerical values of $5,4,3,2$ and 1 respectively.

\subsection{Validation of the Instrument}

The research instrument was validated by two experts in vocational agricultural education from Niger Delta University, Wilberforce Island, Amassoma, Bayelsa State.

\subsection{Reliability of the Instrument}

The instrument (RVAEFSQ) was tested for reliability using test-retest method. 8 copies of the questionnaire were administered to 8 lecturers teaching Agricultural education at the University of Uyo, Akwa-Ibom State. After an interval of 3 weeks, the same questionnaire was redistributed to the same category of respondents. Thereafter, the results from both tests were correlated and tested for internal consistency via Cronbach's Alpha method which yielded a reliability of 0.89 confirming the instrument's reliability.

\subsection{Administration of the Instrument}

The questionnaire was administered by the researcher to all the 24 Agricultural education lecturers in Rivers State University, Port Harcourt and the Ignatius Ajuru University of Education, Rumuolumeni, Port Harcourt. 


\section{International Journal of Social Sciences and Management Review}

\subsection{Instrument for Data Analysis}

The statistical tools adopted for data analysis were Mean and standard deviation. The decision is that any item whose mean value is less than 3.00 was rejected while any item whose mean value is greater than or equal to 3.00 was accepted. Standard deviation values close or wide apart revealed homogeneity in the responses of the respondents.

\subsection{RESULTS}

The results of the study were presented according to the research questions as follows:

Research Question 1: What are the challenges of vocational agricultural education programmes in universities which work against the realization of food security in Rivers State, Nigeria?

\section{Table 1: Challenges of Vocational Agricultural Education in Universities in Rivers State, Nigeria.}

\begin{tabular}{|c|c|c|c|c|}
\hline $\mathbf{S} / \mathbf{N}$ & Item & Mean & SD & Decision \\
\hline 1 & $\begin{array}{l}\text { Agricultural education programmes in universities } \\
\text { in Rivers State lack adequate classroom space. }\end{array}$ & 4.06 & 0.88 & Agree \\
\hline 2 & $\begin{array}{l}\text { Agricultural education programmes in universities } \\
\text { in Rivers State lack modern farm tools and } \\
\text { implements. }\end{array}$ & 4.42 & 1.11 & Agree \\
\hline 3 & $\begin{array}{l}\text { Agricultural education programmes in universities } \\
\text { in Rivers State are taught without pilot farms. }\end{array}$ & 4.21 & 0.94 & Agree \\
\hline 4 & $\begin{array}{l}\text { Agricultural education programmes in universities } \\
\text { in Rivers State are taught without functional library } \\
\text { facilities. }\end{array}$ & 2.89 & 0.98 & Disagree \\
\hline 5 & $\begin{array}{l}\text { Agricultural education programmes in universities } \\
\text { in Rivers State experiences poor electric power } \\
\text { supply. }\end{array}$ & 3.98 & 0.92 & Agree \\
\hline 6 & $\begin{array}{l}\text { Poor welfare packages for lecturers in vocational } \\
\text { agricultural education affects programme output. }\end{array}$ & 3.92 & 0.87 & Agree \\
\hline 7 & $\begin{array}{l}\text { Inadequate vocational agricultural education } \\
\text { lecturers/trainers in Rivers State universities pose } \\
\text { tremendous challenges to programme effectiveness. }\end{array}$ & 4.02 & 1.14 & Agree \\
\hline 8 & $\begin{array}{l}\text { Poor research funding in agricultural education } \\
\text { makes graduates lack creative and innovative skills. }\end{array}$ & 3.68 & 0.81 & Agree \\
\hline 9 & $\begin{array}{l}\text { Poor curriculum and inadequate instructional } \\
\text { materials adversely affect the administration of } \\
\text { Agricultural education in Rivers State universities. }\end{array}$ & 2.74 & 0.79 & Disagree \\
\hline 10 & $\begin{array}{l}\text { Agricultural education programmes in universities } \\
\text { in Rivers State are taught without adequate students' } \\
\text { industrial visitations to Agricultural Research } \\
\text { Institutes. }\end{array}$ & 4.16 & 1.18 & Agree \\
\hline
\end{tabular}




\section{International Journal of Social Sciences and Management Review}

Volume: 03, Issue: 03 "May - June 2020"

ISSN 2582-0176

Grand Mean and Standard Deviation

Source: Field Survey, (2020)

In Table 1 above, all the items constitute challenges to vocational agricultural education programmes in universities in Rivers State as they all have mean values above the criterion Mean of 3.00 except items 4 (2.89) and 9 (2.74) which report otherwise based on the responses of the lecturers. Standard deviation values ranging from 0.79 to 1.18 indicate homogeneity in the responses of the respondents.

Research Question 2: What are the possible ways of tackling the challenges of vocational agricultural education programmes in universities for the realization of food security in Rivers State, Nigeria?

Table 2: Possible Ways of Tackling Vocational Agricultural Education Challenges in Universities in Rivers State for Food Security.

\begin{tabular}{|c|c|c|c|c|}
\hline $\mathbf{S} / \mathbf{N}$ & Item & Mean & SD & Decision \\
\hline 1 & $\begin{array}{l}\text { Provision of conducive classrooms for vocational } \\
\text { Agricultural education in universities in Rivers } \\
\text { State. }\end{array}$ & 4.04 & 1.05 & Agree \\
\hline 2 & $\begin{array}{l}\text { Instructions in Agricultural education in universities } \\
\text { in Rivers State should be administered with } \\
\text { adequate farm implements for practical } \\
\text { demonstration. }\end{array}$ & 4.33 & 0.61 & Agree \\
\hline 3 & $\begin{array}{l}\text { Agricultural education in universities in Rivers State } \\
\text { should be administered with pilot farms to give } \\
\text { hands-on training in agricultural practices to } \\
\text { students. }\end{array}$ & 4.21 & 0.76 & Agree \\
\hline 4 & $\begin{array}{l}\text { Agricultural education programme in universities in } \\
\text { Rivers State needs well-equipped library facilities. }\end{array}$ & 3.98 & 0.86 & Agree \\
\hline 5 & $\begin{array}{l}\text { Agricultural education programmes in universities } \\
\text { in Rivers State need uninterrupted power supply. }\end{array}$ & 4.06 & 0.97 & Agree \\
\hline 6 & $\begin{array}{l}\text { Vocational agricultural education programmes need } \\
\text { adequate funding to be effective. }\end{array}$ & 4.42 & 1.11 & Agree \\
\hline 7 & $\begin{array}{l}\text { More lecturers who specialties are in different } \\
\text { aspects of vocational agricultural education should } \\
\text { be employed in Rivers State universities to enhance } \\
\text { the academic and career training of students. }\end{array}$ & 4.02 & 0.89 & Agree \\
\hline 8 & $\begin{array}{l}\text { Lecturers in vocational agricultural education } \\
\text { should be encouraged to carry out quality research } \\
\text { in food production. }\end{array}$ & 3.97 & 1.06 & Agree \\
\hline 9 & $\begin{array}{l}\text { Graduates of vocational agricultural education } \\
\text { should be encouraged to set up agro-based } \\
\text { businesses of their own for increased food supply. }\end{array}$ & 4.18 & 0.92 & Agree \\
\hline 10 & Students of vocational agricultural education should & 4.32 & 0.87 & Agree \\
\hline
\end{tabular}




\section{International Journal of Social Sciences and Management Review}

\begin{abstract}
pay periodic visits to Agricultural Research
Institutes to acquire external knowledge in

Agricultural production outside the classroom experience.
\end{abstract}

Grand Mean and Standard Deviation

\section{$4.15 \quad 0.91$}

\section{Source: Field Survey, (2020).}

Table 2 revealed that all the items are possible ways of tackling the issues of vocational agricultural education in universities to ensure adequate food supply in Rivers State, Nigeria. This is clearly seen in the mean responses of the lecturers which are all above the criterion Mean of 3.00. Standard deviation values ranging from 0.61 to 1.11 represent closeness in the responses of the respondents.

\subsection{DISCUSSION}

The result of the study as indicated in Table 1 showed that inadequate classroom blocks, lack of pilot farms, poor power supply, inadequate academic staff, defective curriculum among others are some of the challenges of vocational agricultural education programmes in universities which negatively affect food security in Rivers State, Nigeria. This finding was supported by Amadi and Nnodim (2018), who posit that inadequate agricultural education lecturers, is one of the major factors affecting the efficacy and efficiency of vocational agricultural education programmes for massive food supply in Nigeria. Similarly, the finding agrees with Makusidi (2016), who stated that inadequate teaching staff is a major issue affecting vocational agricultural education in Nigeria. Furthermore, the finding corroborates the views of Nnodim and Johnwest (2016), Amadi and Nnnodim (2018) and Nwankwo (2000), who in their separate studies report that inadequate farm tools, equipment and other training facilities are some factors impeding on the development of vocational agricultural education in Nigeria. However, the finding is in contrast to Dipaharima as cited in Ekezie and Owo (2019) and Amadi and Nnodim (2018) who in their different studies report that the curriculum of Vocational Agricultural Education in universities is very rich for the development of agricultural students for increased food production in Nigeria.

The result of the study as contained in Table 2 showed that conducive teaching environment, uninterrupted power supply, the establishment of pilot farms, engagement of more competent lecturers who specialize in different areas of Agricultural education, quality research outputs in agricultural production among others are ways of remedying the issues adversely affecting quality vocational agricultural education in universities which hamper on increased food security in Rivers State, Nigeria. This finding is in line with Ekezie and Owo (2019) who reports that agricultural education programmes if administered properly with tools and pilot farms will result in massive food supply in the country. Similarly, Nnodim and Johnwest (2016) report that adequate farm tools, equipment, and other relevant training facilities are some of the ways we can improve on the state of Agriculture in Nigeria to ensure food security. Thus, from the result of the study, provision of adequate pilot farms, provision of funds for quality agricultural research, improved staff welfares among others are ways of remedying the issue of food insecurity in Nigeria for massive food supply. 


\section{International Journal of Social Sciences and Management Review}

Volume: 03, Issue: 03 "May - June 2020"

ISSN 2582-0176

\subsection{CONCLUSION}

Thus, Nigeria needs to step up its effort in providing food for the teeming population as no meaningful economic development can be achieved when the people are poor, hungry, malnourished especially now that the world is experiencing global corona virus pandemic which tends to cripple the economies of most countries.

\subsection{RECOMMENDATIONS}

Therefore, based on the findings of the study, the following recommendations are suggested:

1. The government should provide adequate facilities in universities for quality training in vocational agricultural education.

2. The government should provide adequate funding for lecturers and researchers to enable them to carry out innovative research in Agricultural production aimed at increased food supply in Nigeria.

3. The government should encourage students of vocational agricultural education to set up agro-based businesses upon successful graduation.

4. The government should encourage Nigerian universities to work in synergy with Agricultural Research Institutes in the country to easily identify areas of deficiency in educational programmes for improvement.

\section{REFERENCES}

Adah, O. C. \& Adejohn, S. O. (2004). The importance of agricultural education in manpower development. Multidisciplinary Journal of Research Development, 9 (5), 81-84.

Akaninwor, G. I. K. (2014). Research methods and Statistics: Paradigms in Education, Science and Technology ( $3^{\text {rd }}$ ed.). Owerri, Nigeria: Civincs publishers.

Amadi, N. S. \& Nnodim, A. U. (2018). Role of agricultural education skills in entrepreneurship development in Rivers State. International Journal of Innovative Social \& Science Education Research, 6 (1), 9 -18.

Arokoyu, A. A. \& Ndeobi, P. C. (2014). Relevance of agricultural education to the development of Nigeria, 21st Century Economy.

Behnassi, M., Draggan, S. \& Yaya, S. (2011). Global Food Insecurity: Rethinking Agricultural and Rural Development Paradigm and Policy. In: Food Crisis Mitigation: The Need for an Enhanced Global Food Governance, Springer Science + Business Media, New York, pp.91-125.

Behnassi, M., Pollmann, O. \& Kissinger, G. (2013). Sustainable Food Security in the Era of Local and Global Environmental Change. Springer Dordrecht Heidelberg, New York. https://doi.org/10.1007/978-94-007-6719-5

Clover, J. (2003). Food Security in Sub-saharan Africa. African Security Review, 12 (1), 1-15. 


\section{International Journal of Social Sciences and Management Review}

Volume: 03, Issue: 03 "May - June 2020"

ISSN 2582-0176

Davies, A. E. (2009). Food Security Initiatives in Nigeria: Prospects and Challenges. Monograph, Department of Political Science, University of Ilorin, Nigeria.

Dipapharima, Z. B. (2004). The role of vocational agricultural education in Nigerian Development. Enugu: OZyBEL Publishers.

Egbuna, E. N. (2001). Food security in Nigeria: The challenges and way forward. A Paper presented at the Annual Conference of the Nigerian Economic Society. Theme: Natural Resource Use, the Environment and Sustainable Development, pp.307-325.

Ekezie, A. I. A. \& Owo, O. T. (2019). Assessment of Agricultural Education Resources for Vocational Skills Development of Students in Universities in Rivers State, SouthSouth, Nigeria. International Journal of Education and Evaluation, 5 (6), 1-14.

Ezeagu, S. E. \& Ezema, P. N. (2004). Introduction to vocational education. Enugu: OZyBEL Publishers.

Food and Agricultural Organization (2010). FAO Statistical Yearbook. Rome: FAO.

Igbinedion, S. O. \& Aihie, J. O. (2015). Towards good governance and sustainable food security in Nigeria: Challenges and the way forward. OIDA International Journal of Sustainable Development, 8 (5), 41-52.

Makusidi, H. M. (2016). The role of vocational agricultural education in national development. Capital Journal of Education Studies, 4 (1), 1-10.

Matemilola, S. \& Elegbede, I. (2017). The Challenges of Food Security in Nigeria. Open Access Library Journal, 4: e4185. Retrieved from https://doi.org/10.4236/oalib.1104185 January 4, 2020.

Muhammad-Lawal, A., Salau, S. A. and Olawusi, C. O. (2015). Sorghum Storage and Pest Control among Farming Households in Kwara State, Nigeria. Tropical Agricultural Research \& Extension, 18, 68-75. https://doi.org/10.4038/tare.v18i2.5326.

Nnodim, A. U. \& Johnwest, E. K. (2016). Vocational skill competence of agricultural science teachers and youth empowerment in Rivers State. International Journal of Education and Evaluation, 2 (3), 51-58.

Nwankwo, C. (2000) Vocational and technical education in Nigeria: Concepts and issues. Enugu: Molsy Fem United Publishers. Pp. 28.

Nwankwo, O. C. (2016). A practical guide to research writing for students in education and social sciences (6th ed.). Port Harcourt: M \& J Grand Orbit and Communication Ltd.

Obinne, C. P. O. (2002). Agricultural science for secondary school certificate, Enugu: New ed, Quality Publishers, Nigeria.

Ojo, E. O. \& Adebayo, P. F. (2012). Food Security in Nigeria: An Overview. European Journal of Sustainable Development, 1 (2), 199-222. 


\section{International Journal of Social Sciences and Management Review}

Olayinka, O. F. (2017). The Right to Food in Nigeria: What is the Impact of University Education on Food Security. In Falaye, F. V. \& Adegbile, J. A. (eds), Issues in Curriculum and Language Education, Ibadan University Press, Ibadan, Nigeria, pp. 411-429.

Otaha, I.J. (2013). Food Insecurity in Nigeria: Way Forward, African Research Review, 7 (4), 26-35.

Usman, M. \& Sulaiman, A. B. (2006). The role of vocational agricultural education in the 21st century. A paper presented at the first national conference of school of vocational and technical education at the FCT college of education, Zuba, Abuja, Nigeria. April 4-6.

Wikipedia, (2016). Agricultural Education. Retrieved from: http://en.m. wikipedia .org /wik/ agriculturaleducation. 02/03/2020. 